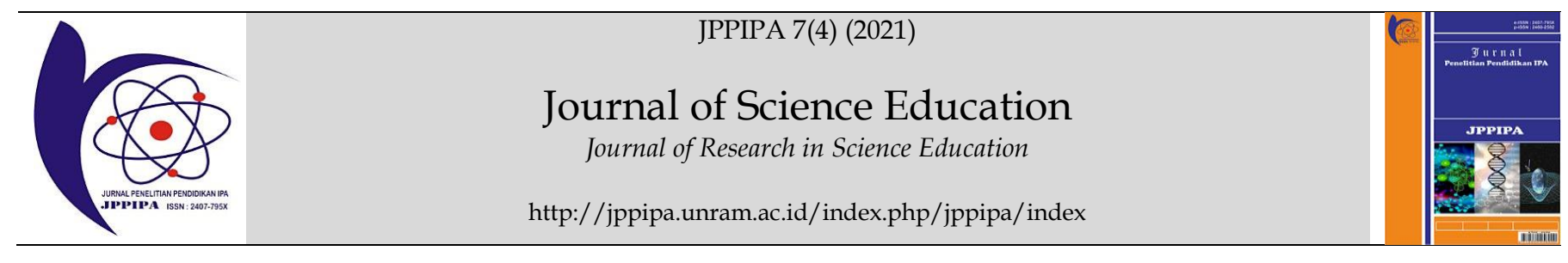

\title{
Analysis Vulnerability Disaster of Landslide in Lantan Village Using Geoelectric Data and Sentinel Image
}

\author{
Syarifatul Ulfah ${ }^{1}$, Marzuki $^{*}$, Adi Susilo² \\ 1,Department of Physics, Universitas Andalas, Limau Manis, Padang 25163, Indonesia \\ ${ }^{2}$ Department of Physics, Brawijaya University, Malang, East Java 65145, Indonesia
}

\section{DOI: $10.29303 /$ ippipa.v7i4.915}

\section{Article Info}

Received : August 24th 2021

Revised : October 10th 2021

Accepted: October 27th, 2021

\begin{abstract}
The vulnerability of landslides in Lantan Village, North Batukliang District, Central Lombok Regency has been analyzed using geoelectric data, rainfall, soil movement, and topographic slope. Resistivity data was acquired by the G-Sound resistivity meter using the dipole dipole configuration method and visualized using the RockWorks15 software. We also used rainfall data and ground movement data. The ground movement was estimated from Sentinel-1A satellite data, processed using the DInSAR (Differential Interferometry Synthetic Aperture Radar) method. The slope data was obtained based on the topographic slope map of the Central Lombok Regency. The results showed that the slip surface was indicated to be located in silt clay with sand and the direction of the erosion in the study area was to the northwest with the type of erosion that might occur was a type A translational erosion. The depth of the slip surface varies from $1.5 \mathrm{~m}$ to 21.5 $\mathrm{m}$. The average monthly rainfall varies from low to high $(<100-300 \mathrm{~mm})$ with a monsoon rain pattern. Land movement in the form of land subsidence was observed at a rate of -0.27 to $-0.30 \mathrm{~cm} /$ year during $2018-2020$, with average land subsidence of $-0.285 \mathrm{~cm} /$ year. The potential for erosions is also seen from the slope value of $40^{\circ}$, which is categorized as very steep. With all these conditions, the level of vulnerability to erosions in Lantan Village is high, and hopefully.
\end{abstract}

Keywords: Landslides; Geoelectric; Slip Surface; Sentinel-1A; Central Lombok

Citation: $\quad$ Ulfah, S. ., Marzuki, M., \& Susilo, A. . (2021). Analysis Vulnerability Disaster of Landslide in Lantan Village Using Geoelectric Data and Sentinel Image. Jurnal Penelitian Pendidikan IPA, 7(4). 794-801. https://doi.org/10.29303/jppipa.v7i4.915

\section{Introduction}

Landslides are one of the natural disasters that often occur when rainfall is high, especially on steep slopes (Crozier, 1986). Landslides occur as a result of natural soil mass transfer, in a short time and with large volumes. Transportation of soil mass occurs at once, so the level of damage caused by the landslide is very large (Aliyatarrafiah \& Widada, 2014).

An area is declared to have a landslide susceptibility level if it has several characteristics such as a fairly steep slope, a subsurface layer that cannot absorb water, non-compact rocks, high intensity rainfall and weathering. Weathering has a significant influence in determining landslides (Bell et al., 2006). This weathering material moves through a plane called the slip plane (Susilo et al., 2018).

The slip plane is a water-resistant (lowpermeability) surface, and usually consists of a hard layer and a soft layer. When it rains, the hard layer (waterproof) will become slippery and the soft layer will move through the impermeable layer so that the impermeable layer acts as a slip plane and the soft layer acts as a landslide material (Yilmaz, 2011).

One of the efforts to minimize the impact caused by landslides is to know areas that are prone to landslides (Agustina, 2014). Among them is through knowledge of the slip field of an area. The depth of the slip plane from the ground surface is very important for the description of landslides. The depth of the slip 
plane is measured from the surface. There are four classes of slip depth, namely very shallow $(<1.5 \mathrm{~m})$, shallow $(1.5-5 \mathrm{~m})$, deep $(5-20 \mathrm{~m})$, and very deep (>20 m) (Aliyatarrafiah \& Widada, 2014 ). The depth of the slip field is important to know because it can inform how big the risk of landslides that will occur. The deeper the slip plane, the higher the landslide hazard. On the other hand, the shallower the slip plane, the lower the landslide hazard (Bell et al., 2006).

Observation of slip plane can be done by geoelectric method. In the investigation research of the landslide slip field that has been carried out in Salaman Hamlet, Pablengan Village, Matesih District, Karanganyar Regency, Central Java Province using the geoelectric resistivity dipole-dipole configuration method, it shows that at the research location the slip field is in the form of a layer of wet clay with a resistivity of $19.3 \mathrm{~m}$ to $36.6 \mathrm{~m}$. The slip depth varies from $1.7 \mathrm{~m}$ to $17 \mathrm{~m}$ (Darsono et al., 2016). The results of research on landslides in Sri Mulyo Village, Dampit District, Malang Regency with the resistivity method, the dipole-dipole configuration shows that below the surface consists of clay $(9.3-85.8 \mathrm{~m})$, tuff $(178-779 \mathrm{~m})$ and breccias ( $1629 \Omega \mathrm{m}$ ). The slip plane in the study area is the boundary between clay and tuff. Dominated by clay with a depth of $10 \mathrm{~m}$. High rainfall, thickness of clay and vegetation (coffee) indicate a high level of vulnerability to landslides. The possible landslide direction is from West-West to Southeast (Susilo et al., 2018). Theoretically, impermeable rock has a large resistivity value and lower permeability. High rainfall causes a weakening of slope stability and an increase in rock loads, thereby increasing the driving force (shear stress) of the rock so that it can trigger soil movement (Darsono et al., 2016). the thickness of clay and vegetation (coffee) indicates a high level of vulnerability to landslides. The possible landslide direction is from West-West to Southeast (Susilo et al., 2018). Theoretically, impermeable rock has a large resistivity value and lower permeability. High rainfall causes a weakening of slope stability and an increase in rock loads, thereby increasing the driving force (shear stress) of the rock so that it can trigger soil movement (Darsono et al., 2016). the thickness of clay and vegetation (coffee) indicates a high level of vulnerability to landslides. The possible landslide direction is from West-West to Southeast (Susilo et al., 2018). Theoretically, impermeable rock has a large resistivity value and lower permeability. High rainfall causes a weakening of slope stability and an increase in rock loads so that it increases the driving force (shear stress) of the rock so that it can trigger ground movement (Darsono et al., 2016).

Ground movement can also indicate landslide susceptibility in an area. Several researchers have conducted research regarding the movement of land that can indicate landslide susceptibility in an area. Islam et al (2017) conducted an analysis of land subsidence in Semarang City using the differential interferometry synthetic aperture radar (DinSAR) method. This method was chosen because it has the ability to assess large areas in a fast time. The DInSAR method used is two-pass interferometry with a $30 \mathrm{~m}$ Shuttle Radar Topography Mission (SRTM) as a reference for topography. This DInSAR process is processed using the open source software SNAP.

Isnaeni \& Farda (2020) conducted an analysis of land subsidence in parts of the city of Semarang in 2017 - 2019 using sentinel-1a imagery and the DinSAR technique. The results of the study showed that there was a land subsidence of $9.5 \mathrm{~cm}$ in a period of two years. Recently, Adfy \& Marzuki (2021) used the DinSAR method to study the potential for landslides in Agam District, West Sumatra.

This article presents the results of research on the potential for landslides in Lantan Village, North Batukliang District, Central Lombok Regency. The environmental conditions of this village are sloped. Based on topographic data, Lantan Village is a hilly area with a slope of $40^{\circ}$ which is categorized as a very steep slope. In the hamlet of Lantan Daye, about 950 meters from the research area, there was a landslide that caused road damage, namely on May 9, 2019 (BPBD, 2019).

Research of the potential landslides in Lantan Village, North Batukliang District, Central Lombok Regency, has been carried out. Permeability and resistivity values have been studied by (Ulfah, 2018). However, further research is needed to analyze the volume of subsurface soil and rock in the study area with 3D inversion so that the depth and direction of the slip plane are obtained. Investigation of subsurface resistivity by applying resistivity surveys in 3D inversion is a technique that takes longer because it has a higher level of difficulty compared to 2D surveys in terms of data acquisition. The results of the depiction of the 3D resistivity distribution obtained have advantages over those obtained from the 2D survey. The depiction of the resistivity distribution generated from the 3D acquisition technique is able to display an image of the resistivity distribution both vertically and horizontally for each different depth. This data acquisition technique with $3 \mathrm{D}$ inversion survey can be applied to determine the distribution of subsurface resistivity in landslide-prone areas (Supper et al., 2008).

Analysis vulnerability of landslides in the study area is also reviewed from the rainfall data to obtain rainfall patterns and rainfall categories in the study area. In addition, ground movement, and the slope of research area were also investigated. Since 2018 - 2020 
there are still frequent earthquakes on the island of Lombok. Although the research area is not the epicenter of the earthquake, it is necessary to know the ground movement that occurs in the form of land subsidence or land level rise as additional data to analyze the vulnerability of landslides from 3D inversion and rainfall data. Ground motion will be estimated from Sentinel-1A image data because this satellite can track in all aspects of the environment, One of them is ground movement. Sentinel-1A data processing using the DInSAR method as done by several previous researchers (Isnaeni \& Farda, 2020; Adfy \& Marzuki, 2021)

\section{Method}

\section{Research Time and Location}

This research was conducted in January - June 2021. The research was conducted in Lantan Duren Hamlet, Lantan Village, North Batukliang District, Central Lombok Regency, which is located at coordinates 8032'02.39" South Latitude and 116018'59.03" East Longitude.

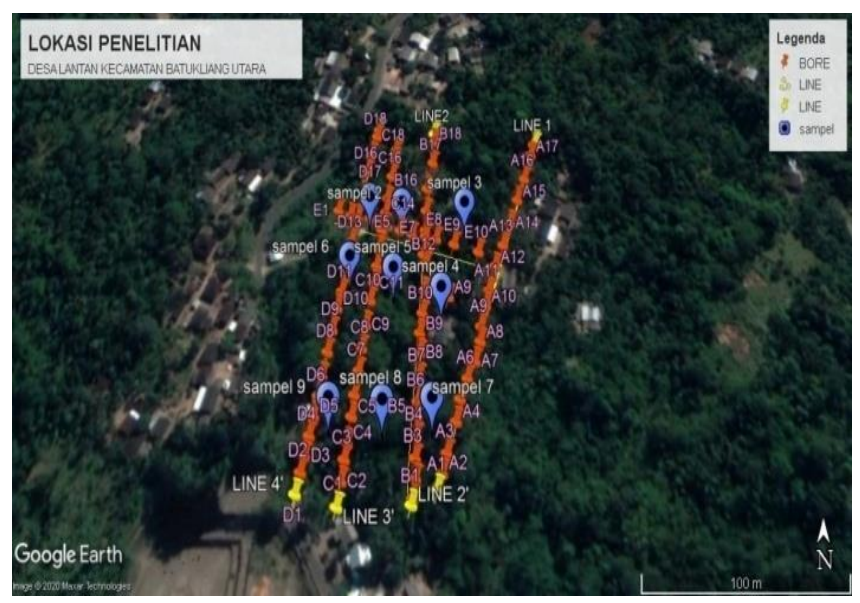

Figure 1. The measurement trajectory of Google Eart Dusun Lantan Duren's imaging results

\section{Tools and Data}

The data used are drill hole data on Google Earth Pro, apparent resistivity data, rainfall data for 2016 to 2020 from the website https://iklim.ntb.bmkg.go.id/dataonline, administrative boundary data in *. shp of North Batukliang District from the website https://tanahair.indonesia.go.id./portal-web and Sentinel-1A image data from the website https://search.asf.alaska.edu. Resistivity data was acquired by the resistivity meter G-Sound using the dipole dipole configuration method. The measurement trajectory can be seen in Figure 1. The software used in this research are Res2divx64 software, RockWork15 software, Google Earth Pro software, SNAP 8.0 software, and Exel 2007 software.

\section{Data processing}

a) Geoelectrical Data

Geoelectric drill hole data that has been correlated with geological data for soil and rock types in the study area is entered into excel. Furthermore, to obtain the value of rock volume, depth, and direction of the slip plane, it is processed using 3D Rockwork15 inversion. In data processing, the first thing to do is open the program. Select the project menu then read the data file whose function is to input data in *.xls format. This data has previously been created with excel software. Select OK and select the scan all boreholes menu. Select the lithology type and enter the color of the soil and rock types. Then select the lithology menu on the text bar. Then, select the model menu and select process. Wait until all drill hole data is read and the lithology volume and depth form in the study area will appear.

b) Rainfall data

Rainfall data from the BMKG website is presented in excel format for both monthly rainy day data and monthly rainfall data from 2016 to 2020. The data is then presented in the form of a time series graph and compared with the grouping of rain in relation to landslides (Liu, et al. ., 2013).

\section{c) Ground Movement Data}

Processing of ground movement data is carried out using the DinSAR method. The DinSAR method attempts to estimate the contribution from the earth's surface ( $\phi$ flat and DEM) which is considered equal for both image acquisitions and removes it from the interferogram so that the remaining phase variation (Equation 1) can be attributed to the change in surface elevation between the two acquisitions (Francis et al., 1996) .

$$
\text { disp }+ \text { atm }+ \text { noise }=-\mathrm{DEM}-\text { flat }
$$

After that, the data is processed using SNAP software. The data obtained is then paired into master and slave data, then image correction is performed to unify the master and slave pixels. The next stage is the formation of the interferogram which is then carried out to remove the topographic phase. This stage subtracts the topographical phase of the processed interferogram. Furthermore, a filtering technique is used to reduce phase noise. After that the phase results are changed in the phase unwrapping process which is done in the SNAPHU software (using the command prompt). The unwrap data from SNAPHU is then converted into a 
phase shift (deformation) in the phase to displacement process. Furthermore, the image geometric correction process is carried out at the geocoding stage, then exported in geotiff format.

\section{Data Interpretation}

The interpretation of geoelectrical data, rainfall and Sentinel-1A imagery is a stage intended to find out the conclusions and results of data processing that will be used to analyze the vulnerability of landslides in Lantan Village, Batukliang Utara District, Central Lombok Regency. At this stage, the results of the Rockwork15 3D inversion geoelectrical data processing in the form of color images are interpreted as resistivity values, subsurface soil types based on the colors that represent them which are first correlated with the geological data of the research area. From here, it can be seen the value of rock volume, depth and direction of the slip plane of the study area. Then based on rainfall data from 2016 to 2020 which has been presented in the form of time series graphs, it is analyzed and compared with rainfall data that causes landslides in the Lantan daye hamlet (950 meters from the research area) as additional data to analyze the potential vulnerability to landslides that will occur. . In addition to geoelectric data, and rainfall data, ground movement data is also used based on displacement images from Sentinel-1A image data processed in SNAP software which has then been mapped using ArcGIS 10.4 software as complementary data to analyze the potential for landslide hazard in Lantan Village, District North Batukliang, Central Lombok Regency.

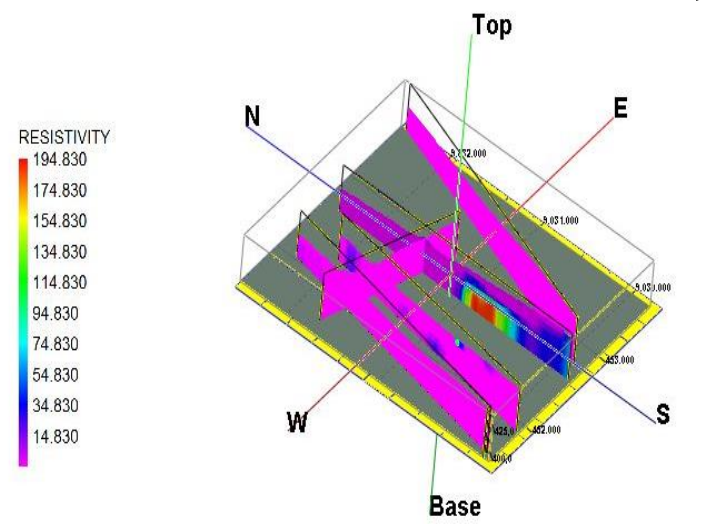

Figure 2. Visualization of combined 1-5 . track resistivity values

\section{Results and Discussion}

\section{Geoelectric Data 3D Inversion}

Figure 2 shows the resistivity values of paths 1 to 5 in Figure 1 using 3D inversion RockWork15 software. The combined results of resistivity values with elevation values ranging from $412 \mathrm{~m}-436 \mathrm{~m}$ obtained a resistivity value of $54.16 \mathrm{~m}-194.830 \mathrm{~m}$.

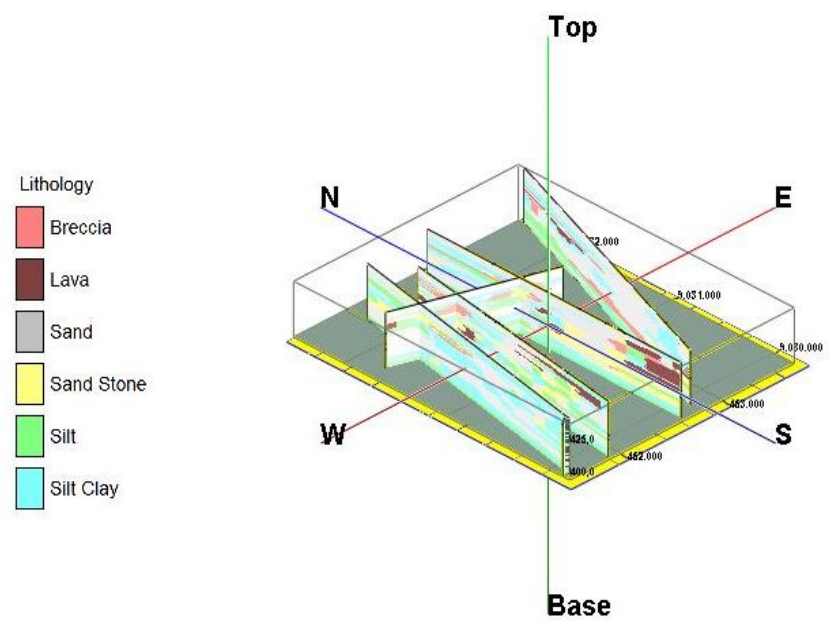

Figure 3. Visualization of Research Area Lithology

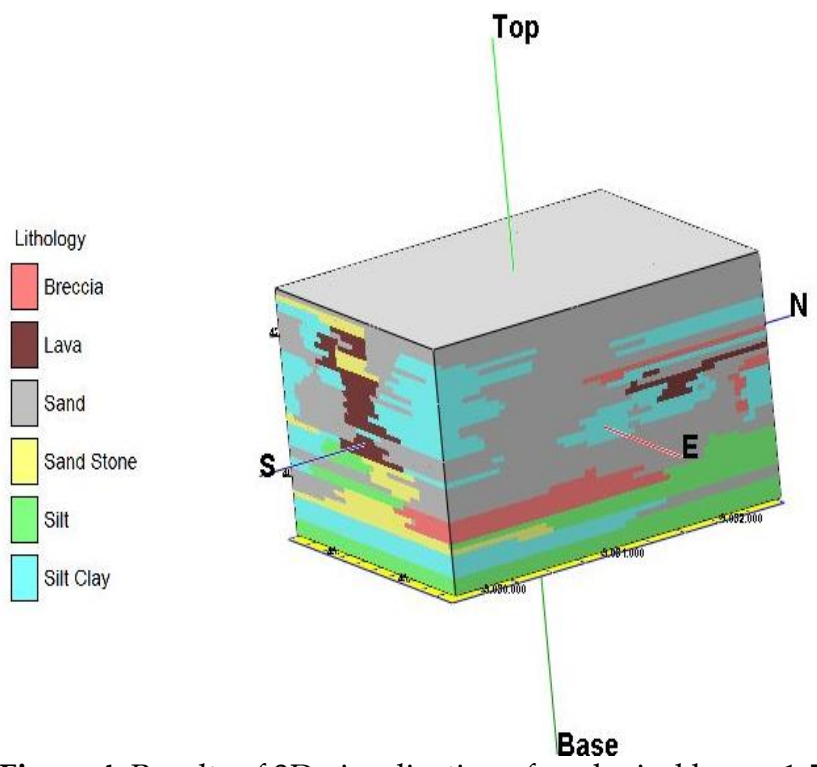

Figure 4. Results of 3D visualization of geological layers 1-5. trajectory

The resistivity value in Figure 2 is then correlated with the geological condition of the study area to determine the composition of the subsurface soil layer of the study area as shown in Figure 3. The composition of the subsurface soil layer in Lantan Duren Hamlet, Lantan Village, North Batukliang District, Central Lombok Regency, consists of 6 soil types. and rocks, namely breccia (red color), lava (brown color), sand (ash color), sandstone (yellow), silt (green), and clay silt (blue color). From the type of soil and rock, the research area includes the types of parameters of high category landslide susceptibility. In accordance with geological constraints or geological disasters that have the potential to be faced and need attention in the research area are soil movements or landslides (Andi Mangga et al, 1994). 
To determine the volume of soil and rock from the study area, 3D visualization was carried out with Rokwork inversion15, and the results can be seen in Figure 4 . The volume of soil and rock in the study area for breccia is $11,235,000 \mathrm{cu} . \mathrm{ft}$, lava is $9,977,500 \mathrm{cu} . \mathrm{ft}$, , $120,000,000 \mathrm{cu}$.ft of sand, 24,610,000 cu.ft of sandstone, $41,150,000$ cu.ft of silt, and $65,277,500$ cu.ft of clay silt. Thus, the research area is dominated by sandy soil types. This is in accordance with the geological conditions of the study area which is dominated by sandy soil types. Sand soil type is a type of soil with high porosity and permeability. Easy to store and pass water. This adds to the load on the rock above or below it. Theoretically,

In addition to the volume of soil and rock from the $3 \mathrm{D}$ visualization results, it is also obtained that the direction of the slip plane is to the Northwest with the type of landslide that may occur is a type A translational avalanche as shown in Figure 5. slip is a type of silty clay soil with sand. Theoretically the slip plane is located between two layers which have contrasting resistivity values. The waterproof layer has a fairly large resistivity value. The resistivity of a rock depends on the porosity of the rock and the type of fluid that fills the pores of the rock. Porous rock that contains water is more conductive and has a low resistivity value. Impermeable rock has a large resistivity value (Susilo et al., 2018). Clay silt has a fairly large resistivity value and is impermeable to water. Clay silt has lower porosity and permeability than sand. Clay silt can only store water but cannot pass water, so when water reaches the clay silt, water will accumulate on the rock which makes the rock slippery and reduces shear strength. Meanwhile, sand with greater porosity and permeability will easily store and pass water. This slippery clay silt will act as a plane where weathering material moves above and below it both down and out of the slope. Material that moves above and below the slippery surface is referred to as landslide material. The slippery area where the landslide material moves is called the slip plane (Ulfah, 2018).

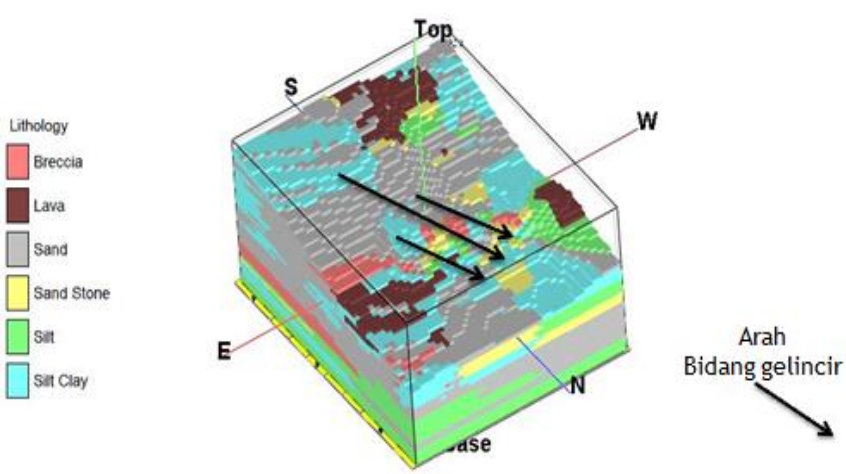

Figure 5. 3d visualization result of slip plane direction
The depth of the slip field obtained in the research area is $1.5 \mathrm{~m}$ to $21.5 \mathrm{~m}$. Theoretically, when measured from the surface there are 4 classes of slip depth, namely very shallow $(<1.5 \mathrm{~m})$, shallow $(1.5-5$ $\mathrm{m})$, deep $(5-20 \mathrm{~m})$, and very deep (>20 m). ) large (Aliyatarrafiah \& Widada, 2014). Based on this value, the study area is categorized as a slip plane from shallow to very deep. The depth of the slip field is important to know because it can determine how big the risk of landslides is. The deeper the slip plane, the higher the landslide hazard. On the other hand, the shallower the slip plane, the lower the landslide hazard (Bell et al., 2006). If it rains with high intensity, in addition to passing water onto the clay silt surface, Sand also stores water which causes an increase in the load of the rock. This can increase the thrust (shear stress) of the rock which can trigger landslides. Thus, the daily and monthly rainfall conditions of the study area are important parameters in the analysis of vulnerability to landslides in this research area, and will be discussed in the next section.

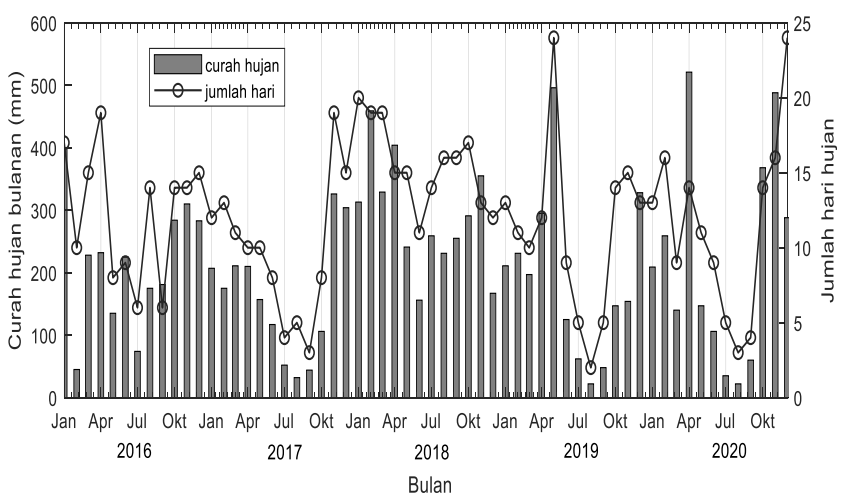

Figure 6. Monthly Rainfall and Number of Rainy Days Monthly 2016 - 2020

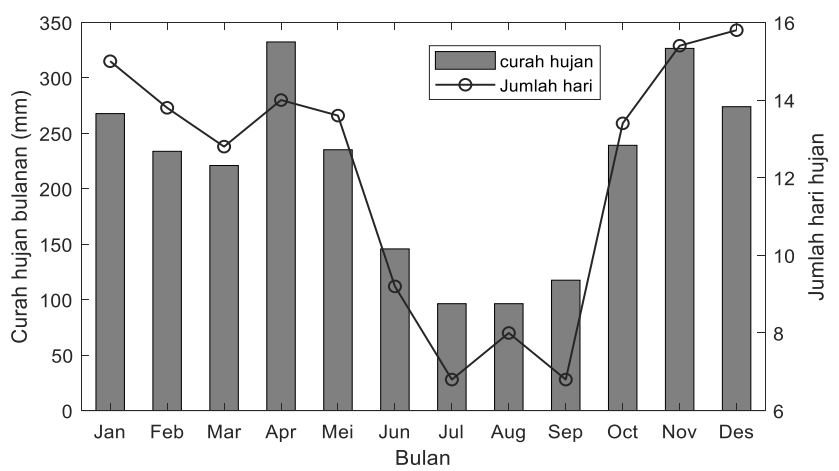

Figure 7. Average rainfall and monthly number of rainy days $2016-2020$

\section{Rainfall}

Figure 6 shows the monthly rainfall and the number of rainy days during 2016 to 2020. The minimum rainy days occur in August 2019 which is 2 
days while the maximum rainy days occur in May 2019 and December 2020 which is 24 days. The peak of the highest rainfall in May 2019 was $496 \mathrm{~mm}$. To see the pattern of the seasons in the study area, the average monthly rainfall and the number of rainy days were calculated as shown in Figure 7. The rainy season starts from October to April while the dry months occurs during May to September. This is in accordance with the distribution of rain zones in Indonesia where Lombok is included in Zone A with one peak of rainfall per year (Aldrian \& Susanto, 2003; Marzuki et al., 2013). Rain in Zone A is influenced by two monsoons, namely the wet northwest monsoon from November to March and the dry southeast monsoon from May to September. Thus, this research area which is included in the Nusa Tenggara region has a monsoon rain pattern (Wheeler \& Mcbride, 2015), the same as the island of Sumatra (Vitri and Marzuki, 2014; Marzuki et al, 2016a; 2016b; 2018).

Monthly rainfall in general can be divided into 4 categories, namely low (0-100 mm), medium (100-300 $\mathrm{mm})$, high $(300-500 \mathrm{~mm})$, and very high $(>500 \mathrm{~mm})$ (Liu, et al. , 2013). Thus, in April and November the rainfall in the study area is in the high category, in January, February, March, May, June, September, October and December it is in the medium category and in July and August it is in the low category. Although the average monthly rainfall in May is classified as medium rainfall. However, in May 2019 the monthly rainfall was included in the high category which caused landslides in Lantan daye hamlet (950 meters from the research area) which caused road damage (BPBD, 2019). This indicates that landslides can also occur in dry seasons.

The duration of the rain will greatly determine the potential for landslides. If the duration of the rain is short, the water will form a runoff, whereas if the duration of the rain is long enough from a few days to several weeks, the water will stagnate and over time will infiltrate into the soil. Soil type will determine whether water will be stored or released to the next soil layer (Veasna, 2005). The slip plane from the results described previously is a layer of clay silt with sand that has different resistivity and permeability values. If it rains with high intensity it will trigger landslides. This rain can trigger landslides or soil movement on slopes composed of soils of low permeability, such as clay soils (Varnes, 1978).

\section{Ground Movement from Sentinel Image}

To see the potential for landslides from the value of ground movement, the Sentinel-1A image was analyzed as shown in Figure 8 . The value of soil movement that occurred in the study area was obtained from $-0.27 \mathrm{~cm} /$ year to $-0.30 \mathrm{~cm} /$ year with an average ground movement of $-0.285 \mathrm{~cm} /$ year. This negative value indicates that the research area is experiencing land subsidence. Land subsidence or commonly referred to as subsidence is an event of land subsidence caused by changes in the volume of the rock layer or soil contained below it. This land subsidence usually occurs slowly and over a long period of time, so we cannot immediately notice the event. Because of this, land subsidence is also often referred to as "

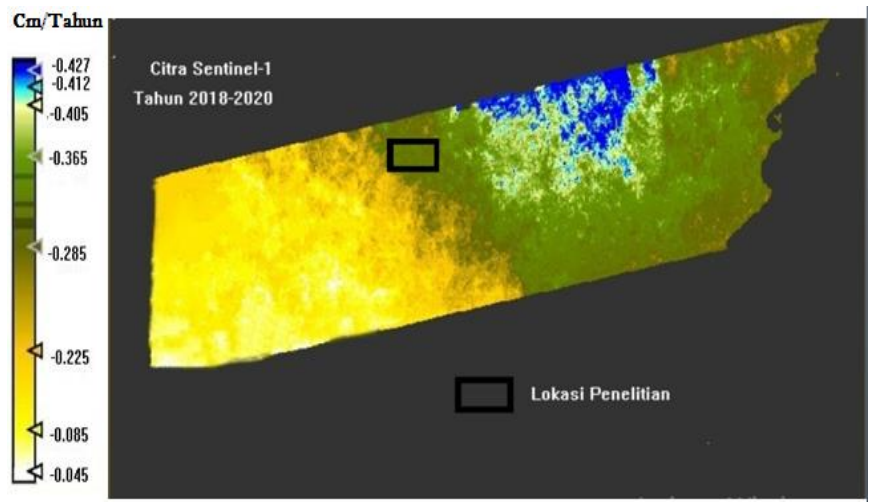

(a)

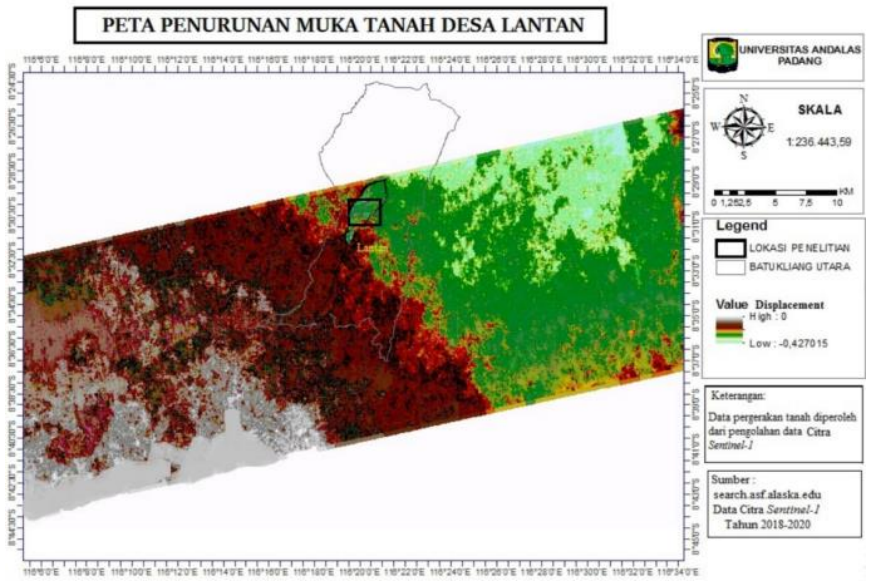

(b)

Figure 8. (a) Sentinel-1 Image Results for 2018-2020

(b) Land Subsidence Mapping Results for 2018-2020

Another factor that causes the research area to be prone to landslides is the slope angle. This slope angle is used as supporting data to analyze the vulnerability of landslides in the research area. Where the slope angle in the research area based on topographic data, Central Lombok Regency is one of the hilly areas with a slope of 40o (Central Lombok Central Statistics Agency, 2017). Theoretically, 35o-55o belongs to a very steep slope. If the stability of the slope is disturbed and the load on the slope increases, the area is prone to landslides. This needs to be considered and as one of the important information for the public to always be aware of disasters that can be caused. 


\section{Conclusion}

The results showed that Lantan Village, North Batukliang District, Central Lombok Regency has a high level of vulnerability to landslides. Geoelectric data indicate that the slip plane is located on clay silt with sand. When viewed from the slip plane, the direction of the landslide is to the northwest and the type of landslide that may occur is a type A translational landslide. The potential for landslides is greater where the study area has an average monthly rainfall of between 100-300 mm, including in the low category to high, with monsoon rain pattern. Land movement in the form of land subsidence of -0.27 to $0.30 \mathrm{~cm} /$ year was observed during $2018-2020$ with an average land subsidence of $-0.285 \mathrm{~cm} /$ year. The slope of the study area is categorized as very steep (40o). With all these conditions,

\section{Acknowledgment}

The present study was partially supported by the Ministry of Research, Technology, and Higher Education (Contract no: 104/E4.1/AK.04.PT/2021). Furthermore, thanks to BMKG for providing rainfall data.

\section{References}

Adfy, DM \& Marzuki (2021). Landslide Hazard Analysis from Rain Characteristics, Land Movements and Slope Slope in Agam District, 10 (1), 8-14.

Agustina, E. (2014). Identification of Landslide Prone Zone with Geoelectrical Resistivity Method of Dipole Dipole Configuration in Payung Batu City. Essay. Department of Physics, FMIPA, State University of Malang.

Aldrian, E., \& Susanto, R. (2003). Identification of three dominant rainfall regions within Indonesia and their relationship to sea surface temperature. Int. J. Climatol., 23, 1435-1452. https://doi.org/10.1002/joc. 950

Aliyatarrafiah, SA, \& Widada, S. (2014). Identification of the Slip Plane with the Resistance Method of Dipole-Dipole Configuration in the Bambankerep Ngaliyan Region, Semarang. Department of Oceanography, Faculty of Fisheries and Marine Sciences, Diponegoro University Semarang, Youngster Physic Journal, 3(4), 291-298. Retrieved from:

https://ejournal3.undip.ac.id/index.php/bfd/art icle/view/7054

Andi Mangga, S., Atmawinata, S., Hermanto, B., \&
Amin, TC (1994). Geological Map Sheet Lombok, West Nusa Tenggara. Geological Research and Development Center, Bandung.

BPBD. (2019). Disaster Learning Guide in Central Lombok Regency. Regional Disaster Management Agency, Central Lombok.

Central Lombok Regency Statistics Agency. (2017). Slope Map of Central Lombok Regency. Central Lombok Regency Statistics Coordinator, Central Lombok.

Bell, R., Kruse, JE., Garcia, A., Glade, T., Bonn, Hordt, A., \& Braunschweig. (2006). Subsurface investigations of erosion using geophysical methods geoelectrical applications in the Swabian Alb (Germany). Geographica Helvetica Jg, 61(3), 201-208. https://doi.org/10.5194/gh-61-201-2006

Crozier, MJ (1986). Landslide: Causes Consequences Environment, Croom Helm, London.

Darsono, D., Nurlaksito, B., \& Legowo, B. (2016). Identifikasi Bidang Gelincir Pemicu Bencana Tanah Longsor Dengan Metode Resistivitas 2 Dimensi Di Desa Pablengan Kecamatan Matesih Kabupaten Karanganyar. Indonesian Journal of Applied Physics, 2, 51. https://doi.org/10.13057/ijap.v2i02.1292 [Indonesian]

Francis P.W., Wadge G., Mouginis-Mark P.J. (1996) Satellite Monitoring of Volcanoes. In: Monitoring and Mitigation of Volcano Hazards. Springer, Berlin, Heidelberg. https://doi.org/10.1007/9783-642-80087-0_8.

Islam, LJF, Prasetyo, Y., \& Sudarsono, B. (2017). Analysis of Land Subsidence (Land Subsidence) of Semarang City Using Sentinel-1 Image Based on Dinsar Method on Snap Software. Undip Journal of Geodesy, 6(2), 29-36. Retrieved from: https://ejournal3.undip.ac.id/index.php/geodesi /article/view/16253

Isnaeni, Y., \& Farda, N. (2020). Analisis Penurunan Muka Tanah Sebagian Kota Semarang Tahun 2017-2019 Menggunakan Citra Sentinel-1A dan Teknik Differential Interferometry Synthetic Aperture Radar (DInSAR). Jurnal Bumi Indonesia, 9(3). Diambil dari http://lib.geo.ugm.ac.id/ojs/index.php/jbi/artic le/view/1196 [Indonesian]

Liu, C., Li, W., Wu, H., Lu, P., Sang, K., Sun, W., Chen, W., Hong, Y., \& Li, R. (2013). Susceptibility evaluation and mapping of China's landslides based on multi-source data. Natural Hazards, 69. https://doi.org/10.1007/s11069-013-0759-y

Marzuki, M., Hashiguchi, H., Yamamoto, M., Yamamoto, M., Mori, S., Yamanaka, M., Carbone, R., \& Tuttle, J. (2013). Cloud episode propagation over the Indonesian Maritime Continent from 10 
years of infrared brightness temperature observations. Atmospheric Research, 120-121, 268286.

https://doi.org/10.1016/j.atmosres.2012.09.004

Marzuki, Hashiguchi, H., Shimomai, T., \& Randeu, W. L. (2016). Cumulative distributions of rainfall rate over Sumatra. Progress In Electromagnetics Research M, 49(April), 1-8. https://doi.org/10.2528/PIERM16043007

Marzuki, M., Hashiguchi, H., Shimomai, T., Rahayu, I., Vonnisa, M., \& Afdal. (2016). Performance Evaluation of Micro Rain Radar over Sumatra through Comparison with Disdrometer and Wind Profiler. Progress In Electromagnetics Research $M$, 50, 33-46. https://doi.org/10.2528/PIERM16072808

Marzuki, H. Hashiguchi, M. Vonnisa, \& Harmadi, (2018) Seasonal and diurnal variations of vertical profile of precipitation over Indonesian maritime continent. Engineering and Mathematical Topics in Rainfall, Doi: https://doi.org/10.5772/intechopen.74044

Supper, R., Römer, A., Jochum, B., Bieber, G., \& Jaritz, W. (2008). A complex geo-scientific strategy for landslide hazard mitigation \&ndash; from airborne mapping to ground monitoring. Advances in Geosciences, 14, 195-200. https://doi.org/10.5194/adgeo-14-195-2008

Susilo, A., Suryo, E. A., Fitriah, F., Sutasoma, M., \& Bahtiar. (2018). Preliminary study of landslide in Sri Mulyo, Malang, Indonesia using resistivity method and drilling core data. International Journal of GEOMATE, 15(48), 161-168. https://doi.org/10.21660/2018.48.59471

Ulfah, S. (2018) Identification of Slip Fields Using Resistivity and Permeability Parameters in Lantan Village, Batukliang Utara District, Central Lombok Regency. Thesis, University of Mataram, Mataram.

Varnes, DJ (1978). Slope Movement and Type and Processes, Landslide Analysis and control, Transportation Research Board. Special Report 176, National Research Council, Washington DC.

Veasna, L. (2005). Effect of Rainfall on Process of Landslide in Tropical Soil in Indonesia. Thesis, Department of Geological Engineering, Faculty of Engineering, Gadjah Mada University.

Vitri, T. \& Marzuki, (2014), Analysis of the Effect of El Nino Southern Oscilation (ENSO) on Rainfall in Koto Tabang, West Sumatra, Journal of Physics Unand, 13 (4), 214-221. doi: https://doi.org/10.25077/jfu.3.4.214-221.2014

Wheeler, MC, \& McBride, J. (2015). AustralianIndonesian Monsoon, In Lau WKM And Waliser DE (Eds) Intraseasonal variability in The
Atmosphere-Ocean climate system, Springer, 125$173 . \quad$ Retrieved from: https://link.springer.com/book/10.1007\%2Fb138 $\underline{817}$

Whitaker, BN, \& Reddish. (1989). Subsidence Occurrence, Prediction, and Control. Elsevier Science Publishing Company INC, Netherlands.

Yilmaz, S. (2011). A case study of the application of electrical resistivity imaging for investigation of a landslide along highway. International Journal of Physical Sciences, 6, 5843-5849. https://doi.org/10.5897/IJPS11.564. 